\title{
Preïmplantatie Genetische Diagnostiek
}

Citation for published version (APA):

de Die-Smulders, C. E. M. (2013). Preïmplantatie Genetische Diagnostiek: ongekende mogelijkheden. Maastricht University. https://doi.org/10.26481/spe.20130906cs

Document status and date:

Published: 06/09/2013

DOI:

10.26481/spe.20130906cs

Document Version:

Publisher's PDF, also known as Version of record

\section{Please check the document version of this publication:}

- A submitted manuscript is the version of the article upon submission and before peer-review. There can be important differences between the submitted version and the official published version of record.

People interested in the research are advised to contact the author for the final version of the publication, or visit the DOI to the publisher's website.

- The final author version and the galley proof are versions of the publication after peer review.

- The final published version features the final layout of the paper including the volume, issue and page numbers.

Link to publication

\footnotetext{
General rights rights.

- You may freely distribute the URL identifying the publication in the public portal. please follow below link for the End User Agreement:

www.umlib.nl/taverne-license

Take down policy

If you believe that this document breaches copyright please contact us at:

repository@maastrichtuniversity.nl

providing details and we will investigate your claim.
}

Copyright and moral rights for the publications made accessible in the public portal are retained by the authors and/or other copyright owners and it is a condition of accessing publications that users recognise and abide by the legal requirements associated with these

- Users may download and print one copy of any publication from the public portal for the purpose of private study or research.

- You may not further distribute the material or use it for any profit-making activity or commercial gain

If the publication is distributed under the terms of Article $25 \mathrm{fa}$ of the Dutch Copyright Act, indicated by the "Taverne" license above, 


\section{Maastricht University}

Oratie

Prof. dr. Christine E.M. de Die-Smulders

Faculty of Health, Medicine and Life Sciences

Preïmplantatie Genetische Diagnostiek: ongekende mogelifkheden 
Preimplantatie Genetische Diagnostiek: ongekende mogelijkheden

Meneer de (pro)rector, college van toezicht en overige belangstellenden. Met deze rede met de titel "Preimplantatie Genetische Diagnostiek: ongekende mogelijkheden" zal ik mijn strategische leerstoel Preimplantatie Genetische Diagnostiek aanvaarden.

Familie, vriendinnen, vrienden en collega's heet ik van harte welkom in Maastricht, een stad met ongekende mogelijkheden. $U$ kunt hier terecht voor coffeeshops, Andre Rieu, en voor preimplantatie genetische diagnostiek.

Ik wil u voorstellen aan het echtpaar V. Meneer en mevrouw zijn beide 25 jaar oud en willen kinderen. In de familie van mevrouw $\mathrm{V}$ is echter recent een jongetje geboren die meerdere aangeboren afwijkingen had en enkele maanden na de geboorte overleed. De oorzaak van de aangeboren afwijkingen was erfelijk. De moeder van het overleden jongetje is de nicht van mevrouw $\mathrm{V}$, en zij bleek drager te zijn van de erfelijke ziekte. Na onderzoek bleek ook mevrouw $V$ drager te zijn van deze erfelijke ziekte. Mevrouw $V$ had net als haar nicht een hoog risico om een kind met aangeboren afwijkingen te krijgen. Het paar $V$ was jong en mevrouw $V$ werd snel zwanger. Het leek aanvankelijk goed te gaan. Om te onderzoeken of hun kind ook de erfelijke ziekte had, besloten zij om een vruchtwaterpunctie te laten doen. In de $16^{\text {de }}$ week van de zwangerschap werd middels een naald wat vruchtwater uit de baarmoeder opgezogen. In de vruchtwatercellen werd het erfelijk materiaal van het kind onderzocht. Uit het vruchtwateronderzoek bleek dat hun ongeboren zoon de erfelijke ziekte had. Het echoscopisch onderzoek door de gynaecoloog van het team voor prenatale diagnostiek liet een kind zien dat én te klein was voor de duur van de zwangerschap én een ernstige hartafwijking had. De levensverwachting werd als somber ingeschat. Zeer verdrietig besloot het paar de zwangerschap af te laten breken. We bespraken met hen de mogelijkheid van preimplantatie genetische diagnostiek. Anderhalf jaar later werd een gezonde dochter geboren, 9 maanden nadat er door de artsen van de IVF afdeling een gezond embryo in de baarmoeder van mevrouw $\mathrm{V}$ was geplaatst.

De methode die we gebruikten is preimplantatie genetische diagnostiek, afgekort PGD, letterlijk diagnostiek voor de innesteling in de baarmoeder, de implantatie. Bij PGD worden, buiten de baarmoeder, embryo's onderzocht en vervolgens wordt een gezond embryo geselecteerd en in de baarmoeder geplaatst. PGD wordt ook wel embryoselectie genoemd. Zo wordt voorkomen dat het kind dat groeit uit het embryo, de erfelijke ziekte krijgt. Om PGD te kunnen uitvoeren is een IVF behandeling, reageerbuisbevruchting, nodig. $\mathrm{Na}$ hormoontoediening aan de vrouw komen meerdere eicellen tot rijping. Deze worden geoogst en in het laboratorium bevrucht met het zaad van de partner. Na de bevruchting ontstaan zo meerdere embryo's. Als de embryo's 3 dagen oud zijn, bestaan ze uit gemiddeld 8 cellen. In al deze cellen is de genetische samenstelling van het toekomstige kind vastgelegd. Er wordt vervolgens 1 cel van elk embryo verwijderd, dat heet de biopsie. Door 
onderzoek van deze ene cel wordt vastgesteld of dat embryo de erfelijke ziekte heeft of niet. 1 dag na de biopsie wordt een gezond embryo in de baarmoeder geplaatst. En dan is het hopen dat er een zwangerschap ontstaat.

PGD onderzoek naar erfelijke ziekten is technisch niet eenvoudig. Er wordt slechts 1 cel van een embryo onderzocht. Deze ene cel bevat ongeveer 6 picogram DNA, dat is een miljoenste van een miljoenste gram DNA, dus een onnoemelijk kleine hoeveelheid. Bovendien moet het onderzoek heel snel, namelijk binnen een dag, klaar zijn. Het embryo moet namelijk snel in de baarmoeder geplaatst worden. Dit alles stelt technische zeer zeer hoge eisen aan het laboratorium en aan de efficiëntie van het PGD team.

Het paar $V$ woonde in het midden van Nederland. Toch kwamen zij helemaal naar Maastricht voor de PGD behandeling. Dat was in het jaar 2000. Het Maastricht Universitair Medisch Centrum, het MUMC+, was en is namelijk het enige centrum in Nederland dat PGD kan en mag uitvoeren en van de overheid een vergunning voor PGD heeft gekregen. In 1995 zijn we op kleine schaal met PGD gestart. Het was toen nog pionieren in de PGD. In 1990 was de eerste PGD behandeling in Engeland uitgevoerd. In Europa is het centrum in Brussel in 1993 met PGD begonnen.

Sinds 1995 zijn bijna 3000 paren op de polikliniek gezien om informatie over PGD te krijgen. Een derde, iets minder dan 1000 paren, hebben gekozen voor een PGD behandeling. Er zijn inmiddels bijna 300 PGD baby's geboren.

Sinds 2008 is het Maastricht UMC met de UMC's van Utrecht, Groningen, en recent met het Academisch Medisch centrum in Amsterdam, gaan samenwerken. Deze 4 Universitair medische Centra zijn verenigd in het samenwerkingsverband PGDNederland. In de 3 transportcentra in Utrecht, Amsterdam en Groningen kunnen paren uit midden en noord Nederland de IVF behandeling die nodig is voor PGD, ondergaan. Dat scheelt veel heen en weer reizen naar Maastricht. De cellen van de embryo's worden vervolgens met een koerier naar Maastricht gebracht en hier onderzocht. Het feitelijke PGD onderzoek gebeurt dus in Maastricht. Met deze constructie van transport PGD blijft de genetische expertise geconcentreerd in Maastricht, terwijl de optimale service naar de patiënten bieden. Een dergelijke organisatie waarin 4 Nederlandse UMC's samenwerken en nog steeds in pais en vree, is uniek, efficiënt én financieel aantrekkelijk.

Ook binnen Europa wordt met belangstelling en soms jaloezie gekeken naar de organisatie van PGD in Nederland.

In de familie van mevrouw $\mathrm{H}, 27$ jaar oud, komt veel borstkanker voor. Haar moeder overleed aan deze ziekte, toen ze slechts 45 jaar oud was. Ook haar oma is overleden aan borstkanker. Recent is bij de zus van mevrouw $\mathrm{H}$, die nu 29 jaar is, ook borstkanker vastgesteld. Er werd een afwijking in een borstkankergen vastgesteld. Ook mevrouw $\mathrm{H}$ zelf heeft de erfelijke aanleg voor borstkanker. Zij heeft $80 \%$ risico om borstkanker krijgen. Zij wil vroeg aan kinderen beginnen, omdat ze weet dat er ook een verhoogde kans op 
eierstokkanker bestaat en het plan is om haar eierstokken te laten verwijderen als ze 35 is. Het paar $\mathrm{H}$ is zeer gemotiveerd voor PGD, zij willen deze vreselijke ziekte, erfelijke borstkanker, niet aan hun dochters doorgeven en willen de ziekte uit de familie bannen. Sinds 2008 hebben 40 paren PGD ondergaan wegens erfelijke borstkanker met 10 kinderen zonder de erfelijke aanleg voor borstkanker als resultaat. Sinds PGD voor erfelijke borstkanker in 2008 werd toegestaan in Nederland, is dit zelfs de meest voorkomende reden om een PGD behandeling te ondergaan.

De families $\mathrm{V}$ en $\mathrm{H}$ illustreren dat er in de loop der jaren een verschuiving is opgetreden in de vraag naar PGD: van PGD wegens ziekten bij pasgeboren en jonge kinderen, naar PGD wegens erfelijke ziekten die zich pas manifesteren op volwassen leeftijd. In de beginjaren achtte men PGD alleen aanvaardbaar bij erfelijke ziekten die al op jonge leeftijd ernstige klachten gaven, zoals in de familie $V$ uit het eerste voorbeeld. Heden ten dage wordt PGD vooral gevraagd en toegepast bij patiënten met de aanleg voor een erfelijke ziekte met begin op volwassen leeftijd, zoals erfelijke borstkanker. Deze patiënten hebben een gezonde jeugd, maar zien zich als jong volwassene geconfronteerd met het feit dat ze ernstig ziek zullen worden op relatief jonge leeftijd. Zij zullen bijvoorbeeld kanker krijgen of chronische psychiatrische en neurologische problemen, zoals bij de ziekte van Huntington. Naast de dreiging en last van hun eigen ziekte hebben deze patiënten $50 \%$ risico om de erfelijke aanleg door te geven aan hun kinderen. Zij zijn vaak zeer gemotiveerd voor PGD. De enige andere manier om de ziekte bij hun kinderen te voorkomen is onderzoek in de zwangerschap en het afbreken van die zwangerschap als het kind dezelfde erfelijke ziekte heeft. Dit onderzoek in de zwangerschap, prenatale diagnostiek, wordt door deze patiënten vaak als zeer problematisch ervaren. Het voelt alsof hun eigen bestaansrecht in twijfel getrokken wordt. PGD biedt dus een goed alternatief om de ziekte bij hun kinderen te voorkomen.

Toch is de introductie van PGD voor erfelijke borstkanker in Nederland niet zonder slag of stoot verlopen. De politieke discussie over PGD bij erfelijke borstkanker, die in 2008 losbarstte, was bijzonder heftig en leidde bijna tot de val van het kabinet Balkenende 4. Kern van de discussie was, naast het gegeven dat de ziekte pas op volwassen leeftijd tot uiting komt, het feit dat erfelijke borstkanker niet altijd kanker veroorzaakt bij vrouwen die wel de erfelijke aanleg ervoor hebben. Van de vrouwen met de aanleg voor erfelijke borstkanker zal namelijk "slechts" 50 a $80 \%$ borstkanker krijgen. Dit betekent dat, als er PGD wordt toegepast, er in tenminste $20 \%$ van de gevallen gezonde embryo's worden vernietigd. De embryo's hebben weliswaar de aanleg voor erfelijke borstkanker, maar de ziekte zal niet optreden. Daarnaast betoogden de tegenstanders dat er voor borstkanker goede mogelijkheden voor preventie zijn, namelijk geregelde controles of amputatie van beide borsten voordat er kanker ontstaat. Bovendien, aldus de tegenstanders, als er toch kanker optreedt, is een goede behandeling mogelijk. 
De tegenstanders en critici van PGD bij ziekten met begin op volwassen leeftijd, zoals erfelijke borstkanker, zijn van mening dat dit type onderzoek leidt tot een devaluatie van de waarde van leven, vooral als dat leven met ziekte gepaard gaat. Er wordt gevreesd dat er een negatief signaal uitgaat naar de maatschappij waarin alleen plaats zal zijn voor gezonde mensen. De critici zijn ook bang dat technieken zoals PGD, de deur openzetten naar diagnostiek en selectie van niet ernstige aandoeningen of zelfs wenselijke eigenschappen. Men vreest de ongekende mogelijkheden.

Mijns inziens doen deze argumenten tegen PGD geen recht aan de grote zorgen van de vrouwen die de aanleg voor erfelijke borstkanker hebben. Ook voordat de ziekte uitbreekt is er voortdurend angst, onzekerheid en stress. De preventieve maatregelen zoals een borstamputatie, zijn zeer zeer ingrijpend.

Het gevolg van de politieke discussie van PGD bij borstkanker is dat in 2009 de kaders voor PGD door de overheid zijn vastgelegd in de regeling PGD. Daarin is opgenomen dat nieuwe indicaties voor PGD worden voorgelegd aan een landelijke richtlijncommissie, die per indicatie beslist of PGD is toegestaan. Enerzijds is met deze Regeling PGD en de instelling van de landelijke indicatiecommissie duidelijkheid geschapen, anderzijds is het voor de betrokken patienten moeilijk te begrijpen dat "een" commissie beslist over hen en hun nageslacht.

Het is evident dat PGD voor paren die serieuze zorgen hebben over het risico op een ernstige erfelijke ziekte bij hun nakomelingen een uitstekende mogelijkheid is om een gezond kind te krijgen. Dit blijkt ook uit de voorbeelden van de paren $\mathrm{V}$ en $\mathrm{H}$, die ik u gaf. Als de vrouw zwanger wordt middels PGD kan ze er vrijwel zeker van zijn dat er een gezond kind op komst is, dat geeft veel rust en zekerheid. Vanuit psychologisch perspectief is PGD te prefereren boven prenatale diagnostiek en een eventuele zwangerschapsafbreking. Het besluit om een gewenste zwangerschap te beëindigen is zeer belastend. Vanuit ethisch perspectief lijkt het selecteren van 3 tot 5 dagen oude embryo's acceptabeler dan het beëindigen van een zwangerschap. Het is dan ook opvallend dat in Nederland PGD al jaren onderwerp is van heftige politieke debatten, terwijl dit voor prenataal onderzoek niet of nauwelijks het geval is.

Ik wil u echter de mogelijk negatieve kanten van PGD niet onthouden. PGD is een belastende behandeling. Het voorbereidend genetisch onderzoek duurt weken tot zelfs maanden. Er is voor dit voorbereidend onderzoek medewerking nodig van familieleden, zodat de genetische varianten die overerven met de ziekte, in kaart gebracht kunnen worden. Paren moeten dus in een vroeg stadium hun familieleden inlichten over hun kinderwens en hun voornemen om embryoselectie te gaan doen.

Elk paar, dat PGD vraagt, ook een normaal vruchtbaar paar, zal een IVF behandeling, reageerbuisbevruchting, moeten ondergaan. Dit is niet zonder risico voor de vrouw. De romantiek van de natuurlijke voortplanting is in het laboratorium ver te zoeken. 
Bovendien is de kans op zwangerschap niet heel groot. Uit onze eigen cijfers blijkt een kans op zwangerschap van 20 a $25 \%$ per PGD behandeling. Uiteindelijk krijgt minder dan de helft van de behandelde paren middels PGD een gezonde baby.

Een andere zorg is de veiligheid en betrouwbaarheid van PGD. Men kan zich voorstellen dat het 3 dagen oude embryo beschadigd wordt door het verwijderen van een cel. Toch zien wij gelukkig niet meer aangeboren afwijkingen bij PGD kinderen. Er zijn echter wel aanwijzingen uit studies dat er na IVF meer kinderen geboren worden met epigenetische defecten.

Epigenetica betreft het aan- en uitschakelen van genen. Of dit voor PGD-kinderen ook geldt, is nog niet onderzocht.

Tenslotte: wij onderzoeken bij PGD slechts 1 cel van een embryo. Deze ene cel bevat bijzonder weinig DNA, zoals $u$ al gehoord hebt. Is zo'n minimale hoeveelheid erfelijk materiaal werkelijk voldoende om betrouwbaar te kunnen vaststellen of het embryo en het toekomstige kind een erfelijke ziekte hebben?

Ik ben blij dat wij met subsidie van Zorgonderzoek Nederland, ZONMW, en het ministerie van VWS, wetenschappelijk onderzoek kunnen doen naar de veiligheid, de betrouwbaarheid en de lange termijn effecten van PGD. We zullen de komende jaren 5 jarige PGD kinderen lichamelijk en neuropsychologisch onderzoeken en deze vergelijken met op natuurlijke wijze verwekte kinderen en met kinderen die geboren zijn middels IVF. In deze studie zal de vakgroep Ethiek van de Universiteit Maastricht tegelijkertijd de ethische en morele aspecten van PGD bestuderen en de ongekende mogelijkheden verkennen.

PGD zal de komende jaren sneller, succesvoller en simpeler worden. De technische mogelijkheden gaan met sprongen vooruit. Op korte termijn zullen we de microarray, de karyomapping en daarna de next generation sequencing invoeren. Met deze technieken zullen we embryo's uitgebreider en goedkoper kunnen onderzoeken. Er ontstaan ongekende mogelijkheden. Embryo's kunnen op meerdere erfelijke ziekten tegelijk onderzocht worden. Het voordeel is dat er nóg gezondere embryo's in de baarmoeder geplaatst worden met nóg een grotere kans op zwangerschap en overleving.

De schaduwzijde is echter dat meer testen niet altijd meer duidelijkheid zal opleveren. Ten eerste gaan de technische ontwikkelingen sneller dan de kennis over de interpretatie van de resultaten. We zullen uitslagen ontvangen waarvan we de exacte betekenis niet begrijpen en dus niet kunnen uitleggen aan paren. Ten tweede kunnen we straks embryo's wellicht zo uitgebreid testen dat er geen $100 \%$ gezond embryo meer bestaat. We kunnen dan slechts besluiten om het embryo met het minst slechte gezondheidsprofiel in de baarmoeder te plaatsen.

We maken kennis met de 38 jaar oude mevrouw T. Na een glansrijke carrière heeft mevrouw $\mathrm{T}$ met haar partner besloten om kinderen te gaan krijgen. Zij komen met de wens om een zo gezond mogelijk kind op de wereld te zetten met optimale maatschappelijke kansen. Er 
wordt een PGD behandeling uitgevoerd. Na het onderzoek zijn er 3 embryo's. Het eerste embryo heeft minder overlevingskans in de baarmoeder, maar zal, als ie overleeft, uitgroeien tot een uiterst succesvol individu. Het tweede embryo heeft een risico op hart- en vaatziekten op oudere leeftijd. Het derde embryo is helaas een meisje, zij hadden graag een stamhouder gehad. Mevrouw T en haar partner zullen een keus moeten maken. Mevrouw T weerspiegelt de toekomst, zoals u wel begrijpt.

Zijn we op weg naar het creëren van de perfecte mens, het creëren van het historisch beladen kind met blauwe ogen en blonde haren? Komen paren in de toekomst daadwerkelijk met deze wensen bij ons in de kliniek? Technisch is het reeds mogelijk om te selecteren op gewenst geslacht. PGD om het gewenste geslacht te bepalen is anno 2013 verboden in Nederland. Paren in Nederland vragen echter zelden om deze selectie op geslacht en laten de keuze jongen of meisje aan de natuur over.

Artsen, andere hulpverleners en beleidsmakers zullen zich bewust moeten zijn van de dilemma's die deze nieuwe technieken met zich zullen meebrengen. We zullen tenminste moeten nadenken wie er gaat beslissen over de ongekende mogelijkheden, beleidsmakers, artsen, patiënten?

Bij geassisteerde voortplanting zoals IVF en PGD, hebben hulpverleners sowieso een bijzondere rol in het beslissingsproces. De hulpverlener heeft een dubbele verantwoordelijkheid, namelijk zowel ten aanzien van de wensouders als ten aanzien van het toekomstig kind. Enerzijds heeft de hulpverlener de plicht om goede zorg te leveren aan de wensouders, bijvoorbeeld IVF met PGD in geval van een verhoogd genetisch risico. Anderzijds mag verwacht worden dat de hulpverlener ook rekening houdt met het welzijn van het toekomstig kind. In uitzonderlijke gevallen, kan bezorgdheid over het welzijn van het kind, een reden zijn om behandeling te weigeren. In de PGD zien we deze verantwoordelijkheid van artsen als een van de aanstaande ouders de genetische ziekte, waarvoor PGD wordt gevraagd, zelf heeft. Bijvoorbeeld als een aanstaande vader of moeder de ziekte van Huntington heeft en al op jonge leeftijd verschijnselen vertoont zoals onwillekeurige bewegingen, karakterveranderingen en dementie. De ziekte zal onvermijdelijk binnen een beperkt aantal jaren tot ernstige neurologische en psychiatrische problemen leiden. Het PGD team zal zich afvragen of het toekomstig kind een veilige basis kan worden geboden en of de gezonde partner de capaciteiten heeft om dit te garanderen.

Een ander voorbeeld. Stelt $u$ zich voor dat een paar al IVF nodig heeft in verband met een vruchtbaarheidsprobleem. De arts is op de hoogte dat er daarnaast ook een genetisch risico bestaat voor het toekomstige kind. De wensouders willen echter geen PGD. Zij vinden het krijgen van een kind belangrijker dan het krijgen van een gezond kind en deze ouders zijn ook niet van plan in een eventuele zwangerschap prenataal onderzoek te laten doen. De arts ziet zich geconfronteerd met het dilemma actief te helpen aan het tot stand komen van een 
zwangerschap terwijl hij of zij zich ervan bewust is dat het toekomstig kind mogelijk een ernstige aandoening zal hebben. Kan er op het paar druk uitgeoefend worden de IVF behandeling wel met PGD te combineren of moeten we dit besluit alleen aan de ouders laten?

Een veelgehoord argument tegen het betrekken van het welzijn van het kind in de besluitvorming is dat paren bij het tot stand brengen van een natuurlijke bevruchting ook vrij in hun keuze zijn. Het verschil echter is de directe en causale betrokkenheid van de arts en het team bij het tot stand komen van de zwangerschap middels IVF met of zonder PGD.

Een mogelijkheid om het ongebreideld testen van embryo's te beperken en toch goede zorg te leveren is het inzetten van preconceptiescreening. Paren met kinderwens krijgen het aanbod zichzelf te laten testen op een aantal vooraf vastgestelde genetische ziektes of eigenschappen die bij hun toekomstige kind problemen kunnen geven. Er is recent in de literatuur een test beschreven waarin ongeveer 500 genen voor ernstige autosomaal recessieve ziektes onderzocht kunnen worden. leder mens is drager van gemiddeld 3 van deze erfelijke ziektes. Dit dragerschap op zich veroorzaakt geen probleem. Echter, als de partner ook drager is van dezelfde ziekte, heeft het paar $25 \%$ risico op een kind met de ernstige erfelijke ziekte.

Als uit de test blijkt dat de ouders een verhoogd risico hebben op een kind met een erfelijke ziekte, kunnen zij voorgelicht worden en kan tot prenatale diagnostiek of tot PGD worden besloten of kan extra onderzoek worden toegevoegd aan de al bestaande PGD indicatie. Embryo's worden wel uitgebreid onderzocht maar slechts op de erfelijke ziekten waarop meer risico bestaat, niet meer en niet minder. Voordeel van deze benadering is dat we wel voorkomen dat er kinderen met ernstige aandoeningen worden geboren, maar niet geconfronteerd worden met onverwachte, moeilijk interpreteerbare bevindingen bij het embryo. Zo beperken we de ongekende mogelijkheden. Het is een gemiste kans dat we in Nederland de deze preconceptiescreening niet of maar zeer beperkt hebben ingevoerd. In een aantal landen rondom de middellandse zee is er al jaren lang een goed draaiend programma van preconceptiescreening. Wij zullen in Maastricht, in samenwerking met onze partners in Nijmegen, het komende jaar, nagaan of we deze 500 genen test preconceptioneel kunnen aanbieden aan bijvoorbeeld paren met een al belaste reproductieve geschiedenis, paren die PGD willen gaan doen en bloedverwante paren. Wij zijn er van overtuigd dat we met het inzetten van deze preconceptionele 500 genen test betere zorg gaan leveren.

Ik heb voor u de praktijk en organisatie van de PGD in Nederland geschetst, de snelle technische ontwikkelingen, de ethische en morele dilemma's en de politieke gevoeligheden. Kortom de gekende en ongekende mogelijkheden. Dit alles overwegende zult u zich wellicht afvragen waar dit heen moet. Is het werkelijk de moeite waard om op een bevolking van 16 
miljoen mensen deze zeer specialistische PGD techniek in stand te houden voor de relatief beperkte groep mensen die hiervoor in aanmerking komen?

Het antwoord is eenduidig ja.......

PGD verdient bestaansrecht. PGD richt zich op zeldzame ziekten. Alle zeldzame ziekten tezamen zijn echter niet zeldzaam meer. Naar schatting overlijden er in Nederland 14.000 mensen per jaar aan een zeldzame ziekte. Ongeveer $80 \%$ van die zeldzame ziektes is erfelijk. De ongekende mogelijkheden van PGD, hebben de afgelopen jaren duizend paren met een hoog risico op kinderen met een genetische ziekte een kans op een gezond kind geboden. Het resultaat is 300 prachtige kinderen en 600 gelukkige ouders.

We staan op het punt om innovatieve technieken in te voeren in de dagelijkse praktijk van de PGD om zo steeds meer mensen sneller en beter te kunnen helpen. Ik zal de verdere ontwikkeling van PGD stimuleren en faciliteren. Ik zal er ook voor waken dat de voortgang verloopt binnen veilige kaders.

Mijn aandacht zal blijven uitgaan naar de trias patiëntenzorg, onderzoek en onderwijs. Wat betreft de patiëntenzorg zullen we de komende tijd in het MUMC+ investeren in EVA. EVA staat voor Erfelijkheid, Voortplanting en Aanleg. EVA is een zogenaamde specialty van het MUMC+. We bieden binnen EVA geïntegreerde en hooggespecialiseerd zorg aan alle mensen met vragen op het gebied van voortplanting en erfelijkheid. Dat betreft paren die zwanger willen worden maar bij wie dat niet lukt, paren bij wie een of meerdere zwangerschappen in een miskraam zijn geëindigd, paren waarbij er later in de zwangerschap complicaties zijn opgetreden of die een kind hebben gekregen met problemen of afwijkingen, al dan niet door een erfelijke oorzaak. Daarbij gaat er aandacht uit naar preventie, zowel preventie van ziektes in de zwangerschap, preventie van erfelijke ziektes, preventie van complicaties bij pasgeborenen alsook preventie van ouderdomsziekten, waarvoor de basis al in de zwangerschap of vroeg in het leven gelegd wordt. Ten tweede bieden we binnen EVA ook gespecialiseerde behandelingen zoals PGD. Dit alles zal worden ondersteund door origineel wetenschappelijk onderzoek.

De verwachtingen rondom EVA zijn hooggespannen. Ik ben ervan overtuigd dat we samen met de afdelingen gynaecologie en kindergeneeskunde van het azM, de afdeling Metamedica van de Universiteit Maastricht en met vele anderen een unieke organisatie met ongekende mogelijkheden neerzetten.

Wat betreft patiëntenzorg wil ik het belang van zorgvuldige counseling rondom PGD benadrukken. Mijn collegae klinisch genetici wil ik stimuleren om, nog meer dan nu het geval is, afwegingen en keuzes rondom kinderwens sámen met het paar te maken. Het slechts noemen van een risico en de mogelijke behandelstrategieën is niet genoeg. Ik kom veel ouders tegen die bang zijn dat hun kind ernstiger ziek zal worden dan zij zelf zijn. Er is nog weinig bekend over de oorzaak van de variabele ernst van erfelijke ziektes. De kunst is om met wensouders af te wegen of PGD gewenst is, ook als er een relatief kleine kans is op 
een ernstige uiting van de ziekte. Het bestaan van een geavanceerde techniek als PGD kan daarbij als dwingend worden ervaren. Hulpverleners vinden dat ze alle beschikbare mogelijkheden moeten aanbieden. Patiënten vinden het moeilijk om deze mogelijkheden af te wijzen.

Van belang is ook het herkennen van geanticipeerde beslissingsspijt. Het willen voorkomen van spijtgevoelens achteraf is een belangrijk motief om wel te kiezen voor PGD. Zelfs paren die te maken hebben met de nadelen van deze methode, zeggen achteraf toch blij te zijn dat ze het geprobeerd hebben. Behandelen geeft namelijk hoop, ook als de kans op succes niet zo groot is. Mensen willen zeker weten dat ze alles gedaan hebben.

Om de voor- en nadelen van de verschillende opties te kunnen wegen, moeten we de achtergrond en denkbeelden van het paar kennen. Deze advisering vergt een individuele aanpak, waarbij de kans op succes en de mogelijke complicaties moeten worden meegewogen. Dit vergt tijd en inspanning. De klinisch geneticus is bij uitstek de arts die hiervoor is opgeleid. De inbreng van andere specialisten is onmisbaar.

PGD zonder goede patiëntenvoorlichting is onverantwoord. Ik hecht er met mijn collega's enorm belang aan dat er tijd en dus financiën voor deze uitgebreide counseling blijft bestaan. Onze counseling mag niet verworden tot de 10 minuten gesprekken die in het onderwijs gebruikelijk zijn.

Financiën zijn ook de reden voor de overheid om het aantal IVF behandelingen terug te willen brengen. Er worden in Nederland per paar en per kind nu 3 PGD behandelingen toegestaan en betaald. De behandeling stopt als er dan geen zwangerschap is ontstaan. Het reduceren van het aantal behandelingen zal rampzalige gevolgen hebben voor de PGD populatie. Het zal het aantal zwangerschapsafbrekingen na prenatale diagnostiek doen stijgen en bevordert de geboorte van kinderen met een genetische ziekte. Immers niet alle paren willen opteren voor prenatale diagnostiek. De zorg achteraf voor een kind met een erfelijke ziekte, of voor een volwassene met een chronische genetische ziekte, zal vele en vele malen zwaarder en duurder zijn dan de PGD behandelingen vooraf. Ik pleit ervoor om het aantal toegestane PGD behandelingen zeker niet te verlagen, sterker nog, te verhogen naar tenminste 4 of liever nog 6.

Ons wetenschappelijk onderzoek zal zich de komende jaren richten op de evaluatie van de resultaten van PGD. We zijn al gestart met vervolgonderzoek van PGD kinderen en zullen dit uitbreiden. De psychologische aspecten en morele dilemma's van ouders krijgen veel aandacht, ook in ons wetenschappelijk onderzoek. PGD bij de ziekte van Huntington en bij erfelijke kanker heeft onze speciale interesse. Met subsidies van het KWF Kankerbestrijding en van Pink Ribbon doen we onderzoek naar de veiligheid en het patiëntenperspectief van PGD bij erfelijke borstkanker. We zullen ook investeren in translationeel en basaal wetenschappelijk onderzoek, met nadruk op de relatie tussen het ontstaan van kanker, embryonale ontwikkeling en verminderde vruchtbaarheid. We weten ons daarbij gesteund 
door de vakgroep Genetica en Celbiologie en onderzoeksschool GROW van de Universiteit Maastricht die zowel de oncologie als de ontwikkelingsbiologie als onderwerp heeft.

Studenten zullen we op de hoogte moeten brengen van de huidige ongekende mogelijkheden in de geneeskunde. Artsen in spé moeten zich bewust worden dat zij een stem hebben bij het bepalen van de grenzen van de geneeskunde. Maatschappelijke thema's mogen niet ontbreken in het onderwijs. Een van de maatschappelijke thema's is de discussie over de leeftijd waarop vrouwen in Nederland kinderen krijgen. Met het stijgen van de leeftijd van de vrouw nemen zowel de hoeveelheid als de kwaliteit van haar eicellen af. Dat zorgt voor een lagere kans op een natuurlijke zwangerschap, en ook op een lagere kans op een zwangerschap middels IVF al dan niet met PGD. Als er ook nog sprake is van een genetische ziekte wordt de beschikbare tijd om een gezond kind te krijgen heel krap. Vrouwen met kinderwens moeten zich hiervan bewust worden. Gynaecologen en klinisch genetici en andere artsen zullen paren met kinderwens en een verhoogd risico tijdig moeten waarschuwen. Van overheidswegen zullen voorzieningen moeten worden uitgebreid: een langer zwangerschapsverlof voor vrouwen en mannen, terugkeergarantie op de werkplek, en goede en goedkope kinderopvang. Onze eigen Universiteit Maastricht kan een belangrijke stimulerende en positieve rol spelen door studenten te steunen als zij tijdens hun studie kinderen krijgen. Bureaucratische hindernissen voor studerende moeders en vaders moeten worden weggenomen.

De klinische genetica en ik zijn samen opgegroeid in de tweede helft van $20^{\text {ste }}$ eeuw. In het toenmalige ziekenhuis Annadal keken we in de 80-er jaren we naar de chromosomen. DNA onderzoek was in de kliniek nog niet beschikbaar. Binnen 1 generatie is de genetica van een argeloos kind uitgegroeid tot een volwassen persoon die zijn plaats in de geneeskunde verworven heeft. Ons technisch kunnen biedt een enorme uitdaging voor verdere groei en wijsheid op geneeskundig en maatschappelijk vlak. De Klinische genetica is in Nederland goed georganiseerd en geconcentreerd in 8 klinisch genetische centra die verbonden zijn aan Universitair Medische Centra. De kwaliteitsstandaard is hoog. De laboratoria zijn gecertificeerd. We hebben een gedegen opleiding tot klinisch geneticus. In Nederland wordt de PGD uitgevoerd in een nauwe samenwerking tussen de afdelingen voortplantingsgeneeskunde, IVF laboratoria en klinisch genetica. We zijn nu aangeland in de $21^{\text {ste }}$ eeuw, de eeuw van de ongekende mogelijkheden.

Per 1 april 2012 ben ik benoemd tot strategisch hoogleraar in de preimplantatie genetische diagnostiek. Ik ben zeer vereerd dat ik de eerste en enige PGD professor ben in Nederland. Ik heb gezegd. 